\title{
CORROSION AND CONSERVATION OF WEAPONS AND MILITARY EQUIPMENT
}

\author{
Bore V. Jegdić ${ }^{1}$, Slavica S. Ristić ${ }^{1}$, \\ Suzana R. Polić-Radovanović, ${ }^{2}$ Ana B. Alil ${ }^{1}$ \\ ${ }^{1}$ Institute GOŠA, Belgrade \\ ${ }^{2} \mathrm{CIK}$, Central Institute for Conservation
}

FIELD: Materials Science (Metals), Mechanical Engineering (Surface Metal Protection Technologies)

ARTICLE TYPE: Review Paper

Summary:

This paper analyzed the conditions for the occurrence of corrosion processes on historically important weapons and military equipment made of steel during the period in outdoor environment. A considerable attention has been given to the characteristics of the most important corrosion products formed on the steel surface. The formation of akaganite, $\beta-\mathrm{FeOOH}$ is a sign of active corrosion under a layer of corrosion products. The conditions that cause the formation and regeneration of hydrochloric and sulphuric acid during the exposure to the elements were analyzed. The most often applied methods of diagnostics and procedures of removing active corrosion anions (desalination) were described as well. The $\mathrm{NaOH}$ solution of certain $\mathrm{pH}$ values still has the most important application for the desalination process. The procedures for cleaning the surface before the application of protective coatings and the application of chemicals that transform rust into stable compounds were discussed. As protective coatings, different types of organic coatings plated on well-prepared steel surfaces were used and sometimes special types of waxes as well. This paper presents the results of the tests of corrosion products taken from the exhibits of weapons and military equipment from the Military Museum in Belgrade.

Key words: (regular): arms and military equipment, conservation, steels, corrosion, corrosion products.

\section{ACKNOWLEDGEMENTS:}

The work was financed by the Ministry of Education and Science of Serbia, Project No. 34028, and by the Ministry of Culture of Serbia. 


\section{Introduction}

Corrosion is the destruction of metals and alloys caused by chemical or electrochemical reaction with the surrounding environment [1]. Electrochemical corrosion is a result of the electrochemical reactions and liable to the law of the electrochemical kinetics. This includes all cases of corrosion in a humid atmosphere, in the soil, as well as corrosion in the electrolyte solutions. During electrochemical corrosion, two or more electrochemical reactions occur on metal surface at the same time. An anodic reaction is the dissolution of metal or transition metal ions in the solution, while a cathodic reaction is the reduction of oxidation agents occurring in the solution. It is usually the reduction of oxygen. In acidic media, the reduction of hydrogen ions occurs [1-3] at the same time.

Anodic current (current of metal dissolution) is called corrosion current Icorr and it can be taken as a measure of the corrosion process rate. Faraday's law connects the mass of dissolved metal with a value of corrosion current. In general (uniform) corrosion, anodic and cathodic reactions take place on the same surface, so the corrosion rate is expressed through the relation of the current and the surface, i.e. the corrosion current density, $j_{\text {corr }}=I_{\text {corr }} / \mathrm{A}$. In the case of localized forms of corrosion, anodic and cathodic currents must also be equal, but the anodic and cathodic surface areas can be very different, because the dissolution of metal is much more intensive at some places [3].

Weapons and military equipment made of steel underlie to corrosion during the process of exploitation in the outdoor environment. On their surface a layer of corrosion products (rust) is gradually formed, with corrosion aggressive ions, such as chloride and sulphate anions, often incorporated in the rust structure. When certain weapons or military equipment get out of use and become important artifacts of cultural heritage, they are properly processed and conserved and become available, in the museums, to the future generations.

\section{The types of corrosion}

General (uniform) corrosion is characterized by a uniform decrease of the thickness of metal, without significant localized attacks. During this type of corrosion, the replacement of anodic and cathodic sites occur, resulting in approximately equal dissolution of metal on the whole metal surface. The corrosion rate is usually expressed by the penetration of corrosion into the depth of metal, in definite time and expressed in the $\mu \mathrm{m}$ year ${ }^{-1}$. This form of corrosion is much less dangerous related to the localized forms of corrosion. On the metal surface, more or less insoluble layer of corrosion products can be formed, slowing down the progress of further corrosion [3]. 
Galvanic (contact or bimetallic) corrosion occurs during the contact of two or more different metals or alloys in the presence of electrolyte. The basic conditions for the appearance of this type of corrosion are an electrical contact between dissimilar metals, the presence of electrolyte and the potential difference between metals in contact. A layer of atmospheric moisture or hygroscopic salts and impurities on the metal surface can play the role of the electrolyte. A great impact for the occurrence of galvanic corrosion has the conductivity of the electrolyte, where corrosion is more intense when the conductivity of the electrolyte is higher. Corrosion is limited to the narrow surface of metal in contact at low electrolyte conductivity. At higher conductivity of the electrolyte, corrosion can occur at larger distances between different metals. For contact corrosion, the potential difference between metals is essential. If the potential difference is greater, contact corrosion is more intense. Based on the galvanic series of metals (ASTM G 82) we can predict the behaviour of different metals in contact, in corrosion environments in particular. As it is known, galvanic series are series of metals arranged in order of increasing values of their electrode potentials in certain corrosion environments. During the contact corrosion, the anode to cathode surfaces ratio is important. If the lower metal surface with anodic behaviour is in relation to the metal surface with cathodic behaviour, the more intense is the corrosion of anode metal $[3,4]$.

Pitting corrosion is a highly localized corrosion attack which forms corrosion holes (pits). It was found that pits are formed in the areas of destruction of the protective film on the metal surface. If the film is damaged mechanically or chemically, it should be restored or a pitting corrosion process will occur. In the presence of halide ions, especially $\mathrm{Cl}^{-}$ions, pits formation usually occurs. While the temperature increases, the tendency of metals and alloys to form pits also increases. The formation of stable pits on the steel surface will not occur if the temperature is lower than some critical value, which is called the critical pitting temperature [3].

Crevice corrosion more often occurs in the places of contact between structural elements, if they form a crevice magnitude of $0.1 \mathrm{~mm}$. The phenomenon of crevice corrosion is based on differential aeration. In areas with higher concentrations of oxygen, the cathodic reaction takes place, while in places with lower concentrations the anodic reaction occurs. Therefore, due to a difficult access of oxygen, steel within the crevice is rapidly dissolved. Also, due to the hydrolysis of metal ions in crevices, acidic environment forms reducing the $\mathrm{pH}$ value, which further accelerates the metal dissolution process. This type of corrosion follows similar laws as pitting corrosion. If there is a greater conductivity of electrolyte and a bigger cathodic metal surface outside the crevice, the rate of metal dissolution in the crevice is higher $[3,5]$.

Intercrystalline corrosion is a form of local corrosion, manifested by the dissolution of the grain boundary area. An improper heat treatment of some aluminium alloys or austenitic and ferritic stainless steels causes the precipitation of certain phases at grain boundaries and then fast inter- 
granular corrosion [3]. This type of corrosion causes a large deterioration in the mechanical properties of metals. Intergranular corrosion is not found in structural carbon steel, and it will not be further considered.

Selective corrosion (dealloyng) is a form of corrosion which leads to the selective dissolution of less rare alloy components. For example, the selective dissolution of $\mathrm{Zn}$, so-called dezincification, takes place on brass surfaces and leaves a porous, mechanically weak matrix of $\mathrm{Cu}$. The presence of chloride ions and the increase in temperature accelerate dezincification. Selective corrosion occurs in other alloys, e.g. graphitization in cast iron, dealuminization in Al-bronze, or denikelization in Cu-Ni alloys [3].

Stress corrosion cracking is a process which occurs when the necessary electrochemical, mechanical and metallurgical conditions exist. When hydrogen ions are present at the crack tip as the product of corrosion reactions, the crack growth can occur by the process of local hydrogen embrittlement. These processes are often the cause of fractures in exploitation. The environments that cause stress corrosion cracking are usually water-based and they can be solutions or adsorbed moisture layers. Stress corrosion cracking usually takes place by influence of specific ions present in the corrosion environment. For example, stress corrosion cracking of the brass, traditionally called a season cracking, usually occurs in the presence of $\mathrm{NH}_{4}{ }^{+}$ ions. Chloride ions cause cracking of aluminium alloys and stainless steel, while hydroxyl ions cause cracking of structural carbon steel. Stress corrosion cracking usually starts at surface defects formed during mechanical processing, welding, etc. It can also start at surface defects created during the process of corrosion, such as pitting, intercrystalline corrosion, etc. [3].

Microbiological corrosion is a form of corrosion in which micro organisms play an important role. Micro organisms can initiate or accelerate corrosion processes. For example, certain micro organisms, present in water or other corrosion environments, can produce a bio film on the metal surface. Since the metal surface is not uniformly covered by the bio film, a concentration cell is formed and corrosion processes initiated. In addition, the metabolic products of micro organisms can cause the acidification of the local environment. It changes the corrosion behaviour of metals. The changed kinetics of anodic and cathodic reactions affects the protective properties of the surface film or causes the formation of corrosive deposits [3].

\section{The environmental factors that cause damage}

Most types of structural carbon steels corrode when exposed to the outdoor environment without protective coatings. A layer of rust formed on the steel surface is porous, poorly adherent and it often cracks. Layers of rust provide little protection to the base metal from the effects 
of oxygen and moisture. Cracking and destruction of rust layers occur as a consequence of the formation of new corrosion products of steel whose molar volume is approximately three times higher than the molar volume of steel. Generally, carbon steels have a higher corrosion rate in the outdoor environment than aluminium, copper, lead or zinc, particularly in industrial and coastal conditions [6,7]. Some corrosion products formed on the steel surface exposed in the open air are shown in Table 1.

Corrosion of steel is an electrochemical process: anodic reaction is oxidation of $\mathrm{Fe}$ to $\mathrm{Fe}^{2+}$ ions and the cathodic reaction is usually a reduction of dissolved oxygen. When $\mathrm{Fe}^{2+}$ ions are present in a solution, different types of corrosion products can be formed and can precipitate on the steel surface. A rust layer generally includes the inner layer of black magnetite, $\mathrm{Fe}_{3} \mathrm{O}_{4}$ (and other amorphous steel corrosion products) and the outer layer of iron oxy-hydroxide: goethite, $\alpha-\mathrm{FeOOH}$, lepidocrocite, $\gamma$-Fe$\mathrm{OOH}$ and akaganite, $\beta-\mathrm{FeOOH}$. Other corrosion products can be formed, depending on the ions present in the environment $[6,7]$.

Sulphate ions accelerate the steel corrosion rate. Iron (II) sulphate compounds are formed when steel corrodes in the presence of sulphate ions. During the evaporation of water, iron (II) sulphate crystallize (rozenite, Fe$\mathrm{SO}_{4} 4 \mathrm{H}_{2} \mathrm{O}$, siderotile, $\mathrm{FeSO}_{4} 5 \mathrm{H}_{2} \mathrm{O}$, melanterite, $\mathrm{FeSO}_{4} 7 \mathrm{H}_{2} \mathrm{O}$ ). In the presence of moist air, iron (II) sulphate oxidizes and hydrolyzes by reaction [8]:

$$
\mathrm{FeSO}_{4}+1 / 4 \mathrm{O}_{2}+3 / 2 \mathrm{H}_{2} \mathrm{O} \rightarrow \mathrm{FeOOH}+2 \mathrm{H}^{+}+\mathrm{SO}_{4}{ }^{2-}
$$

It can be seen from reaction (1) that the precipitation of iron oxyhydroxides (lepidocrocite, goethite) occurs, and sulphate ion appears in the form of sulphuric acid. Sulphuric acid gives to sulphate ions a capability of re-action on the remaining metal surface, forming a corrosion cycle. A certain amount of sulphate ions is removed from the solution (corrosion cycle) because they are incorporated into the layer of rust as a relatively insoluble iron (III) hydroxide sulphate, as butlerite, jarosite or natrojarosite.

Table 1. Some corrosion products identified on a steel surface exposed to the outdoor environment [6].

Tabela 1. Neki korozioni produkti identifikovani na površini čelika izloženih otvorenom prostoru [6].

\begin{tabular}{|c|c|c|c|}
\hline Chemical name & Mineral name & Chemical formula & Color \\
\hline Iron oxide & Magnetite & $\mathrm{Fe}_{3} \mathrm{O}_{4}$ & Black \\
\hline Iron oxy-hydroxide & Goethite & $\alpha-\mathrm{FeOOH}$ & Yellow-brown \\
\hline Iron oxy-hydroxide & Akaganeite & $\beta-\mathrm{FeOOH}$ & Red-brown \\
\hline
\end{tabular}




\begin{tabular}{|c|c|c|c|}
\hline Iron oxy-hydroxide & Lepidocrocite & $\mathrm{Y}-\mathrm{FeOOH}$ & Orange \\
\hline $\begin{array}{c}\text { Iron sulphate } \\
\text { tetrahydrate }\end{array}$ & Rozenite & $\mathrm{FeSO}_{4} 4 \mathrm{H}_{2} \mathrm{O}$ & Green \\
\hline $\begin{array}{c}\text { Iron sulphate } \\
\text { pentahydrate }\end{array}$ & Siderotil & $\mathrm{FeSO}_{4} 5 \mathrm{H}_{2} \mathrm{O}$ & White \\
\hline $\begin{array}{c}\text { Iron sulphate } \\
\text { heptahydrate }\end{array}$ & Melanterite & $\mathrm{FeSO}_{4} 7 \mathrm{H}_{2} \mathrm{O}$ & Blue-green \\
\hline $\begin{array}{c}\text { Iron hydroxide } \\
\text { sulphate dihydrate }\end{array}$ & Butlerite & $\mathrm{Fe}(\mathrm{OH}) \mathrm{SO}_{4} 2 \mathrm{H}_{2} \mathrm{O}$ & Orange \\
\hline $\begin{array}{c}\text { Iron potassium } \\
\text { hydroxide sulphate }\end{array}$ & Jarosite & $\mathrm{Fe}{ }_{3} \mathrm{~K}(\mathrm{OH})_{6}\left(\mathrm{SO}_{4}\right)_{2}$ & Yellow-brown \\
\hline $\begin{array}{c}\text { Iron sodium } \\
\text { hydroxide sulphate }\end{array}$ & Natrojarosite & $\mathrm{Fe}{ }_{3} \mathrm{Na}(\mathrm{OH})_{6}\left(\mathrm{SO}_{4}\right)_{2}$ & Yellow-brown \\
\hline
\end{tabular}

Chloride ions are easily transported through the layer of rust where they can attack steel, form soluble salts and the complexes of iron chloride, and cause a rapid corrosion of steel. During the corrosion of steel in the solutions containing low concentrations of chloride ions, goethite and lepidocrocite start to precipitate; however, at higher concentrations of chloride ions, the other iron oxy-hydroxide, known as akaganite, is formed. Akaganeite is usually written as $\beta-\mathrm{FeOOH}$; however, since chloride ions incorporate and stabilize its structure, the chemical formula that includes chloride ions is $\mathrm{FeO}_{0.833}(\mathrm{OH})_{1.167} \mathrm{Cl}_{0.167}$. Chloride ions increase the corrosion rate of steel, because they participate in the following corrosion cycle [9]:

$$
\begin{aligned}
& 2 \mathrm{Fe}+4 \mathrm{H}^{+}+4 \mathrm{Cl}^{-}+\mathrm{O}_{2} \rightarrow 2 \mathrm{Fe}^{2+}+4 \mathrm{Cl}^{-}+2 \mathrm{H}_{2} \mathrm{O} \\
& 2 \mathrm{Fe}^{2+}+4 \mathrm{Cl}^{-}+3 \mathrm{H}_{2} \mathrm{O}+1 / 2 \mathrm{O}_{2} \rightarrow 2 \mathrm{FeOOH}+4 \mathrm{H}^{+}+4 \mathrm{Cl}^{-}
\end{aligned}
$$

The most important stage in this cycle is that chloride ions form a soluble salt with iron (II) ions, which allows that the cycle flows. If the iron (II) chloride is insoluble, then it will be precipitated and the cycle will be broken.

Crevice corrosion can occur on any metal sculpture in the outdoor environment, but it usually occurs under crevices, for example on complex weapons and military equipment [10-13]. Gaps exist on the metalmetal joints or joints metal-other material, such as seals, biological or external sludge deposits. The rate of diffusion of oxygen into gaps is limited, so an oxygen concentration cell is formed within the crevice area $[5,6]$. This area becomes anodic and corrodes (Fig. 1). The acidity and concentration of dissolved metal ions in the gap increase, causing a significant increase of the corrosion rate of steel. The progress of crevice corrosion is frequently observed visually by leaking outside the crevice edge of the dissolved corrosion products of steel. 


\section{The desalination of weapons and military equipment}

In the conservation of the museum artifacts of weapons and military equipment, the diagnostic of the exhibits with different non-destructive methods is a very important step. Visual observations of archaeological artifacts covered with a thick layer of corrosion products are not possible for the estimation of how much is left of non-corroded metal and whether there are cracks or other defects in the base metal (Fig. 2a). Most authors consider that the radiographic method is the most reliable to evaluate the amount of non corroded steel, and the types and forms of damage (Fig. 2b). Multiple radiographic examinations give reliable results [14]. Fig. 3 shows the artifacts from the weapons collection in the Military Museum in Kalemegdan, during the radiographic examination.

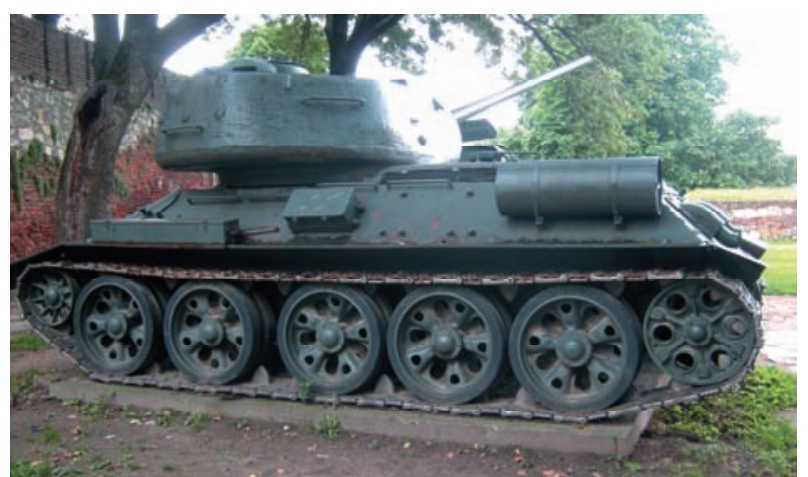

Figure 1. Russian tank T34 from World War II (Military Museum in Belgrade) Slika 1. Ruski tenk T34 iz drugog svetskog rata (Vojni muzej u Beogradu)

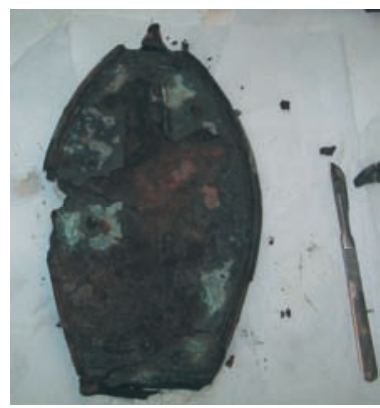

a)

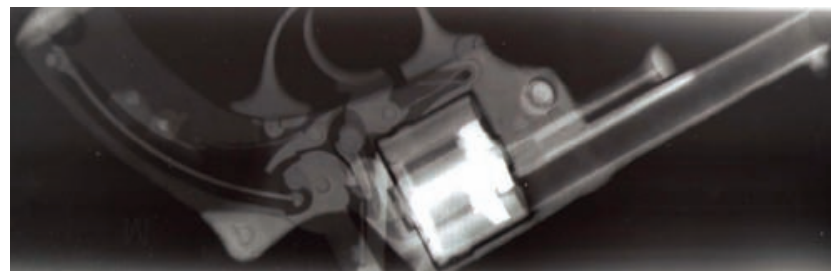

b)

Figure 2. a) Fibula from the Roman times BC (before conservation), covered with a layer of corrosion products (Museum in Novi Sad), b) Radiographic image of an MS 4 revolver (Museum in Smederevo)

Slika 2. a) Kopča iz rimskog perioda pre nove ere (pre konzervacije), prekrivena slojem korozionih produkata (Muzej u Novom Sadu), b) radiografski snimak revolvera MS 4 (Muzej u Smederevu) 
Another important step before the conservation is desalination of artifacts. The desalination treatments of corroded, historically important artifacts of weapons and military equipment are designed to remove as many chloride ions as possible from the layer of corrosion products (Figure 2a). Alkaline solutions, which allow the desorption of chloride ions and also lead to the passivation of the iron and steel surface, are usually applied [7,15].

North and Pearson [16] have developed a model that describes the process of diffusion of chloride ions from the layer of corrosion products, where, as they assumed, $\mathrm{Cl}^{-}$ions are equally distributed within the layer of corrosion products. Their model, considered as a uniform model, gives an overall picture of the diffusion of chloride ions from the surface of artifacts of any shape. The model predicts that the chloride ions diffuse into the desalination solution immediately after their immersion, because they are uniformly distributed in a layer of corrosion products. Another model of the diffusion of $\mathrm{Cl}^{-}$ions, developed by Selwyn et al. [17], is based on the fact that the chloride ions in the initial period are concentrated on the border between the steel surface and a layer of corrosion products. The model (abrupt model) predicts a time delay before the appearance of chloride ions in the desalination solution. The time delay corresponds to the period required for the diffusion of chloride ions from their initial position at the border with the steel surface, through the layer of corrosion products and finally into the desalination solution.

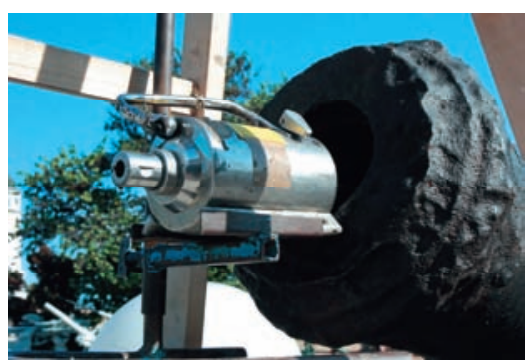

a)

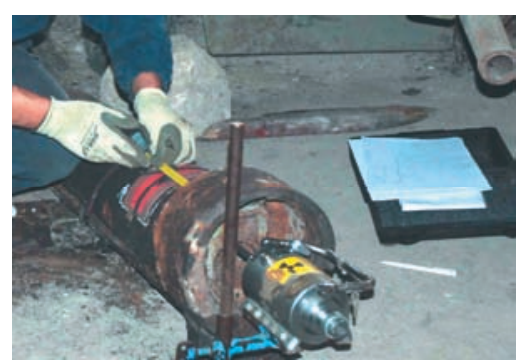

b)

Figure 3. Radiographic recording a) barrel of the French ship cannon, AN 1808 RUELLE, b) barrel of the French cannon 75/27 model 1911 Deport (Military Museum in Kalemegdan in Belgrade)

Slika 3. Prikaz radiografskog snimanja: a) cev francuskog brodskog topa AN 1808

RUELLE, b) cev francuskog topa75/27 model 1911 Deport (Vojni muzej u Beogradu)

Two key factors that affect the ability of chloride ion diffusion out of corrosion products are: whether the steel still corrodes in the desalination solution and whether the layer of corrosion products is porous enough to allow the diffusion of $\mathrm{Cl}^{-}$ions into the solution [15]. If steel corrodes during the process of desalination, chloride ions will be attracted to new ions generated by $\mathrm{Fe}^{2+}$ corrosion and will prevent their diffusion into the surrounding solution. In the alkaline solution on the steel surface, a protective film of iron (II) 
hydroxide is formed and gradually transformed into low soluble iron (III) hydroxide. Conservators usually used aqueous solutions of $\mathrm{NaOH}(0.1$ to $0.5 \mathrm{~mol} \mathrm{dm}^{-3}, \mathrm{pH}$ 13-14) for the treatment of steel artifacts, and neutral EDTA solutions for treating non-ferrous metals and complex artefacts made of iron (steel) and other non-ferrous metals $[15,18]$. The treatments in $\mathrm{NaOH}$ solutions are very effective because of their high $\mathrm{pH}$ values that help in stopping the corrosion process by the passivation of steel surface, reducing the gradient of the electrical potential on its surface [15].

In order to reduce the steel corrosion rate, treatments that remove oxygen from the desalination solution are sometimes applied. Inert gas (e.g. nitrogen) passing through the solution is also applied $[6,15]$. Oxygen scavengers are used as well, such as sodium sulphite $\left(\mathrm{Na}_{2} \mathrm{SO}_{3}\right)$. In addition to neutral sodium sulphite, the application of an alkaline solution known as alkaline sulphite $\left(0.5 \mathrm{~mol} \mathrm{dm}^{-3} \mathrm{NaOH}+0.5 \mathrm{~mol} \mathrm{dm}^{-3} \mathrm{Na}_{2} \mathrm{SO}_{3}, \mathrm{pH} 13.5\right)$ has recently been found [15]. One of the procedures that slows down the steel corrosion rate and facilitated the diffusion of chloride ions is the application of different types of electrochemical treatments [15]. In this case, the artifact must have a significant non-corroded metal core. Fig. 4 shows the composition of the crystalline phases present in the corrosion products taken from Cannon 75/27, prior to its conservation. The radiographic diagnostics and the testing of composition corrosion products are performed on this artifact [19]. It can be seen that, in addition to common corrosion products, the corroded steel surface shows the presence of akaganite, $\beta-\mathrm{FeOOH}$, which contains incorporated chloride ions in their crystal structure.

The concentration of extracted chloride ions is usually continuously measured during desalination processes (eg. from $\mathrm{NaOH}$ solutions). The potentiometric titration, the ion-selective electrode or the ion chromatography methods are applied in order to determine the moment when chloride ions are almost completely extracted from the layer of corrosion products [15].

\section{The conservation of weapons and military equipment}

Conservators carry out the conservation procedures with the least possible damage to the weapons and military equipment in order to save them for the next generations. They take into account historical significance of artifacts and tend to maintain, as much as possible, the original materials by using the techniques that minimally damage metal surfaces. Conservators choose renewable coatings that can be removed and applied again in the future. Reparations of damaged parts or replacements of missing parts are often done. Galvanic corrosion is avoided by 
applying the same material as the one weapons and military equipment were made of or by applying non-conductive materials to separate different metals (non-conductive polymers, teflon, seals, etc.). When the direct contact between dissimilar metals cannot be avoided, a risk from galvanic corrosion is reduced by applying the metals that are located in the galvanic series as close to the original ones as possible $[3,6]$.

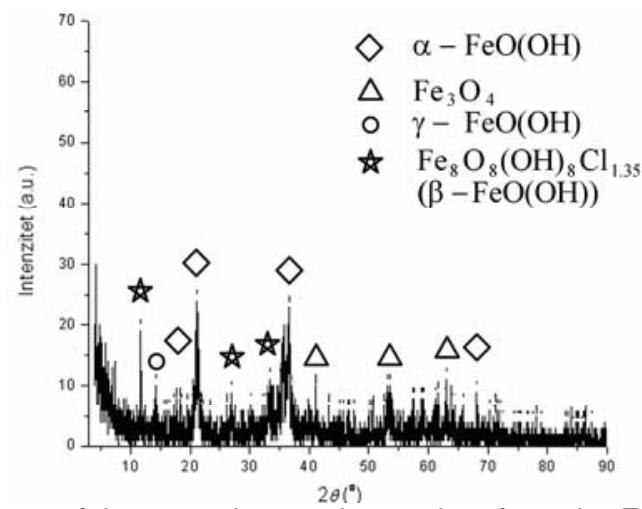

Figure 4. XRD diagram of the corrosion products taken from the French Cannon 75/27 model 1911 Deport.

Slika 4. XRD dijagram korozionih produkata uzetih sa francuskog topa 75/27 model 1911. Deport.

Cleaning and maintenance of the immediate environment of artifacts are carried out during the regular inspections of artifacts. Accumulated debris, leaves, and possibly the nests of birds and animals should be removed. Trees and local vegetation are cut down to allow a good air circulation and to deter birds. Graffiti are removed and damage identified in order to take repairing measures. Artifacts are washed with mild soap and water to remove accumulated dirt, salt and bird droppings. To repair small defects, wax coatings are applied. Frequent controls help in faster identification of problems $[3,6]$.

Before removing old organic coatings, their content is tested for lead. Rigorous precaution conditions must be guaranteed upon the removal of such coatings because of the toxicity of lead. Red lead was used in the past as a barrier layer with very strong inhibitor properties, and white one as a pigment in organic coatings, for outdoor use. Organic coatings that contain lead are forbidden in many countries today [6].

The standard procedure for surface preparation before applying the organic coating is to remove all kinds of dirt, old coatings, existing rust, either chemically (eg., phosphoric acid, chemicals for removing organic coatings) or mechanically (e.g. abrasive blast). The drawback in the application of chemicals is that they can penetrate into the inner space, where it is difficult to remove them completely. Chemical removal of organic coatings or rust is usually limited to weapons and military equipment that can be completely disassem- 
bled, cleaned, rinsed and reassembled. When applying the method of abrasive blast cleaning, the choice should be made among the materials and methods that least damage metal surface (e.g. soft abrasives and low pressures) and efficiently remove the surface material without damaging the historical importance of the base metal. The method of dry abrasive cleaning was used to remove organic coatings and rust from the surface of weapons and military equipment. The wet abrasive method is not commonly used because of some problems with subsequent rusting wetted areas of metals. However, this method is particularly suitable for removing pollution containing chlorides and sulphates on the steel surface. Unless soluble salts are removed prior to the application of organic coatings, it will cause premature deterioration of coatings [6].

Another approach to the preparation of rusted steel surfaces before applying the organic coatings is to remove rust and impurities that can be easily removed, while retaining the compact layer of rust with good adhesion on the metal surface. The steel surface is then treated with a chemical agent that converts rust, and the organic coating is applied $[3,6]$. Chemical agents for the rust conversion contain a polymer component (which accepts the cover compatible polymer coating) and tannic acid (which reacts with rust and form a blue-black film iron (III) tannate).

The application of organic coatings on steel is a common and effective method of controlling the process of rusting. It is important to apply a compatible system of the organic coatings according to the manufacturer's instructions. When the steel surface is properly cleaned (with removed chloride ions as well), the first basic grunt layer of the organic coating is applied and then the final cover layer of the compatible organic coating. A large number of different basic layers and the final cover organic coatings for the corrosion protection of weapons and military equipment in the outdoor environment are used [20]. Alkyd coatings are often used because of their relatively efficient protection against atmospheric corrosion and are easy to maintain [3,6]. Fig. 5 shows the conserved weapons from the collections of the Military Museum in Belgrade, shown in Fig. 3 during the radiographic examinations.

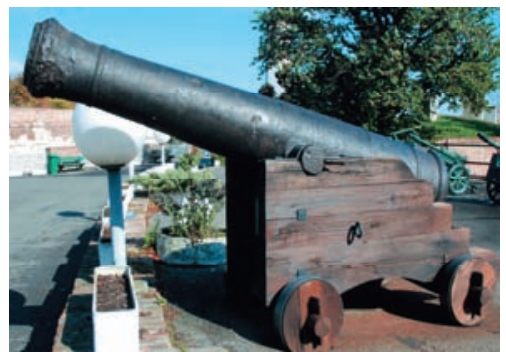

a)

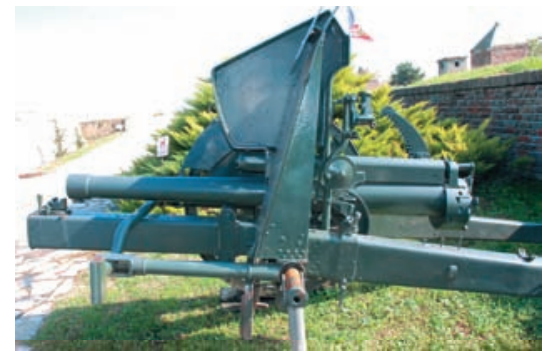

b)

Figure 5. a) French ship cannon AN 1808 RUELLE b) French Cannon, model 75/27 1911 Deport (Military Museum in Belgrade)

Slika 5. a) francuski brodski top AN 1808 RUELLE, b) francuski top 75/27 model 1911 Deport (Vojni muzej u Beogradu) 
The application of wax coatings (and other coatings to prevent corrosion) is another method used to control rusting of weapons and military equipment in the outdoor environment. The applications of these coatings do not require complete removal of the existing rust and old organic coatings. It is necessary to degrease and remove dirt, as well as old coatings and rust layer of weak adhesion. Cleaning in the blast soft organic abrasive is confirmed as effective. Mixtures of waxes, such as these used to protect the surface of outdoor bronzes, are used for protection of steel surfaces containing a thin layer of rust with good adhesion. The commercial chemical products used to prevent corrosion (rust) were also used. These products, dried by solvent evaporation and based on petroleum, leave a protective film on the steel surface (the film often looks like wax), which provides some protection against corrosion in the outdoor environment. These products are used to protect military sculptures, industrial machinery and cast iron cannons [6].

\section{Conclusions}

This paper analyzes the corrosion processes on steel, the procedures to remove the corrosion active ions present in the layer of corrosion products (desalination) as well as the conservation of artifacts of weapons and military equipment.

The conditions affecting the corrosion processes in weapons and military equipment made of steel in the outdoor environment were analyzed. A considerable attention has been given to the description of the most important formed corrosion products. A sample of the corrosion products taken from Cannon 75/27 is given as an illustration of the experimental testing of the results. The corrosion product (akaganite, $\beta-\mathrm{FeOOH}$ ) whose formation on the surface of the artifact is a sign of active corrosion of steel under a layer of corrosion products, identified on the cannon, is described.

In addition, the conditions that lead to the formation and regeneration of hydrochloric and sulphuric acid during the periods spent in the outdoor environment were discussed. The most applied procedures of removing corrosion active anions from the layer of corrosion products (desalination) were described. A desalination process in the $\mathrm{NaOH}$ solution of certain $\mathrm{pH}$ values still has the greatest application.

The paper also describes the metal surface cleaning before the application of protective coatings and the use of chemical agents that transform rust into a form of stable compounds. Various types of organic coatings, applied on the well-prepared surface of steels, are commonly used as protective coatings as well as special types of waxes.

\section{Literature}

[1] Revie, R. W. and Uhlig, H. H.: Corrosion and Corrosion Control: An Introduction to Corrosion Science and Engineering, John Wiley \& Sons, New Jersey, 2008. 
[2] Landot, D.: Corrosion and Surface Chemistry of Metals, Lausanne, Switzerland, 2007.

[3] Polić-Radovanović, S., Ristić, S., Jegdić, B. i Nikolić, Z.: Metodološki i tehnički aspekti primene novih tehnika u zaštiti kulturne baštine, Centralni institute za konzervaciju u Beogradu i Institut Goša, Beograd, str. 141-230., ISBN 978-86-86917-12-6

[4] Baboian, R.: Galvanic Corrosion, Corrosion: Fundamentals, Testing, and Protection, Vol. 13A, ASM Handbook, ASM International, Ohio, 2003, pp. 210-213.

[5] Kelly, R. G.: Crevice Corrosion, Corrosion: Fundamentals, Testing, and Protection, Vol. 13A, ASM Handbook, ASM International, Ohio, 2003, pp. 242-247.

[6] Selwyn, L.: Corrosion of Metal Artifacts Displayed in Outdoor Environments, Corrosion: Environments and Industries, Vol. 13C, ASM Handbook, ASM International, Ohio, pp. 289-305.

[7] Selwyn, L.: Metals and Corrosion: A Handbook for the Conservation Professional, Canadian Conservation Institute, 2004.

[8] Graedel, T. E. and Frankenthal, R.P.: Corrosion mechanisms for iron and low alloy steels exposed to the atmosphere, Journal of the Electrochemical Society, Vol. 137, No. 8, pp. 2385-2394, 1990.

[9] Askey, A., Lyon, S. B., Thompson, G. E., Johnson, J. B. Wood, G. C. Cooke M. and Sate, P., The Corrosion of Iron and Zinc by Atmospheric Hydrogen Chloride, Corrosion Science, Vol. 34, No. 2, pp. 233-247, 1993.

[10] Jovičić, S., Primena sredstava za zaštitu od korozije-put ka ekonomičnijem održavanju, Vojnotehnički glasnik /Military Technical Courier, Vol. 57, No. 2, pp. 94-100, ISSN 0042-8469, UDC 623+355/359, Beograd, 2009.

[11] Ilić, S. i Marjanović, G., Fenomen erozije cevi naoružanja, Vojnotehnički glasnik/Military Technical Courier, Vol. 57, No. 3, pp. 28-42, ISSN 0042-8469, UDC 623+355/359, Ministarstvo odbrane Republike Srbije, Beograd, 2009.

[12] Majkić, Z. Đ. and Vukčević, N. S., Analiza vrsta I lokacija veza i nekih konstruktivnih zahteva pri ugradnji različitih tipova nadgradnji na transportna vozila, Vojnotehnički glasnik/Military Technical Courier, Vol. 59, No. 2, pp. 120-141, ISSN 00428469, UDC 623+355/359, Ministarstvo odbrane Republike Srbije, Beograd, 2011.

[13] Donevski, D. V., Metodologija izbora naoružanja za primenu na lakim terenskim točkaškim vozilima, Vojnotehnički glasnik/Military Technical Courier, Vol. 59, No. 2, pp. 29-40, ISSN 0042-8469, UDC 623+355/359, Ministarstvo odbrane Republike Srbije, Beograd, 2011.

[14] Thickett, D., Lambarth, S. and Wyeth, P.: Determining the Stability and Durability of Archaeological Materials, $9^{\text {th }}$ International Conference on NDT of Art, Jerusalem, Israel, 25-30 May 2008, pp. 1-10.

[15] Selwyn, L.: Overview of archaeological iron: the corrosion problem, key factors affecting treatment, and gaps in current knowledge, Proceedings of Metal 2004, National Museum of Australia, Canberra, 2004, pp. 4-8.

[16] North, N. A. and Pearson, C.: Washing Methods for Chloride Removal from Marine Iron Artifacts, Studies in Conservation Vol. 23, No. 4, pp. 174-186, 1978.

[17] Selwyn, L., McKinnon, W. and Argyropoulos, V.: Models for Chloride Ion Diffusion in Archaeological Iron, Studies in Conservation Vol. 46, No. 2, pp. 109-120, 2001. 
[18] Stanković, S., B. Grgur, B., Krstajić, N. and Vojnović M.: Kinetics of the zinc anodic dissolution reaction in near neutral EDTA solutions, Journal of the Serbian Chemical Society, Vol. 68, No. 3, pp. 207-218, 2003.

[19] Jegdić, B., Ristić, S., Polić-Radovanović, S., Alil, A. and Rajaković-Ognjanović, V.: Corrosion of Cannon 75/27, model 1911. Deport, from collection of the Military Museum in Belgrade, FME Transactions (submitted article).

[20] Bučko, M. i Vujičić, V., Ispitivanje mogućnosti primene poliamid-polietilenske folije za konzervaciju tehničkih sredstava, Vojnotehnički glasnik/Military Technical Courier, Vol. 56, No. 4, pp. 48-55, ISSN 0042-8469, UDC 623+355/359, Ministarstvo odbrane Republike Srbije, Beograd, 2008.

\section{KOROZIJA I KONZERVACIJA NAORUŽANJA I VOJNE OPREME}

OBLAST: materijali (metali), mašinstvo (tehnologije površinske zaštite metala)

VRSTA ČLANKA: pregledni rad

Sažetak:

U radu su razmotreni uslovi pri kojima dolazi do korozije istorijski važnog naoružanja i vojne opreme izrađenog od čelika tokom perioda provedenog na otvorenom prostoru. Znatna pažnja posvećena je razmatranju karakteristika najvažnijih korozionih produkata koji se pri tome obrazuju na površini čelika, među kojima i akaganita, $\beta$-FeOOH, čije obrazovanje predstavlja znak aktivne korozije čelika ispod sloja korozionih produkata. Analizirani su uslovi koji dovode do obrazovanja $i$ regeneracije hlorovodonične, odnosno sumporne kiseline tokom perioda provedenog na otvorenom prostoru. Opisane su najčešće primenjivane metode dijagnostikovanja i postupci uklanjanja koroziono aktivnih anjona iz sloja korozionih produkata (desalinacija). Najveću primenu još uvek ima postupak desalinacije u rastvoru $\mathrm{NaOH}$ određene $\mathrm{pH}$ vrednosti. Razmotreni su postupci čišćenja površine pre nanošenja zaštitnih prevlaka i primena sredstava koji transformišu rđu u hemijski stabilna jedinjenja. U svojstvu zaštitnih prevlaka se koriste različite vrste organskih prevlaka nanešenih na dobro pripremljenu površinu čelika, a nekada se takođe koriste specijalne vrste voska. U radu je prikazan deo rezultata ispitivanja korozionih produkata uzetih sa eksponata naoružanja i vojne opreme Vojnog muzeja u Beogradu.

Ključne reči: naoružanje $i$ vojna oprema, konzervacija, čelici, korozija, korozioni produkti.

Datum prijema članka: 11. 10. 2011.

Datum dostavljanja ispravki rukopisa: 24. 11. 2011.

Datum konačnog prihvatanja članka za objavljivanje: 25. 11. 2011. 